\title{
Quasi-Alliance at Play: The Curious Case of South Korea's Aborted Withdrawal from GSOMIA in 2019
}

\author{
Resi Qurrata Aini ${ }^{1}$, Yandry Kurniawan ${ }^{2}$ \\ ${ }^{1}$ Department of International Relations, FISIP, Universitas Indonesia \\ (email: resi.qurrata91@ui.ac.id, resi.aini1@gmail.com) \\ ${ }^{2}$ Department of International Relations, FISIP, Universitas Indonesia (email: yandryk@ui.ac.id)
}

\begin{abstract}
This study aims to explain why countries maintain security cooperation with a partner even though they are in the middle of severe tensions. This is experienced by the Republic of Korea (ROK), which preferred to maintain its security cooperation with Japan under the General Security of Military Information Agreement (GSOMIA). This research utilizes the concept of abandonment fears to explain South Korea's behavior in reversing its self-declared withdrawal from GSOMIA in 2019. By conducting a deductive-qualitative research approach, this research shows that South Korea was in a position of abandonment fears - fears of being ignored by Japan - magnified by the uncertainty of US commitment. For now, South Korea considers Japan as the most likely partner choice in the region. Thus, Seoul decided to maintain the partnership with Japan within the GSOMIA framework and compromise its grievances with the latter.
\end{abstract}

\section{Keywords:}

South Korea-Japan Relations; security cooperation; military agreement; quasi-alliance; abandonment fears

\section{Introduction}

States yearn for stable regional security since it could significantly affect their security as well. Regional stability is influenced by the interaction of states within the region and the influence of external powers. Apart from the relationships between actors, the patterns of the dominant behavior of entities and institutions are also essential in shaping regional orders: the power and behavior of regional powers, conflict, cooperation, regional integration, and interference from external powers (Ponizilova, 2017, p. 182). States aim to survive in the unknown international political arena (Suseto, Othman, \& Razalli, 2019). One way to achieve that goal is by joining the security cooperation or alliance in the region. This was also what encouraged South Korea and Japan to sign
General Security of Military Information Agreement (GSOMIA). ${ }^{1}$

Each region has its characteristics that shape the way states interact with each other. So does East Asia, whose interaction is colored by competition and antagonism. South Korea and Japan are geographically located in East Asia with a tendency to have cold, if not hostile relations. What is unique about their interaction is that despite their shared ally (the United States) and adversaries (China, Russia, and North Korea), all these similarities cannot

\footnotetext{
1 General Security of Military Information Agreement (GSOMIA) is a commonly used term regarding intelligence and sensitive military information sharing between countries. It was signed by South Korea and Japan on $23^{\text {rd }}$ of November 2016 under the framework of Agreement on the Protection of Classified Military Information.
} 
make South Korea and Japan closer allies. This relates to the fact that South Korea was under Japanese rule from 1910 to 1945 as stipulated in the Japan-Korea Treaty 1910. During that time, South Korea experienced Japan's colonial brutality and, until now, this historical memory has overshadowed the relationship between the two countries (Korostelina, 2017) and has often been a trigger for tensions.

South Korea and Japan have committed to GSOMIA since 2016, with the support from the United States. This security cooperation is renewed every year unless one country declares its withdrawal. GSOMIA is strategically essential for South Korea because it enables South Korea and Japan to directly share intelligent information about missile threats from North Korea. South Korea-Japan security cooperation is considered a quasi-alliance since they are not directly connected if there is no backup from the United States, their common ally.

The year 2018-2019 was such a tremendous period for South Korea-Japan relations. Some media and Northeast Asian security affairs observers and pundits even considered this as the worst period of South Korea - Japan relations since the normalization pact in 1965 (M. C. Lee, 2019). The tension was stimulated by the reemergence of the Women Comfort issue in South Korea. During the Asia Pacific War (1937-45), Japan forcibly employed at least 200,000 women from various Japanese colonies in Asia to serve Japanese soldiers in brothels called comfort stations (Min, 2003, p. 938; Hayashi, 2008, p. 127). South Korean women were also forced to work without payment for the Mitsubishi Aircraft Plant in Nagoya in 1944 (bbc.com.2008). The court ordered the Japanese company, Mitsubishi Heavy Industries, to pay compensation to the forced laborers for 80-150 million Won (Japan Press Weekly, 2018). Aside from that, the Japanese government was also required to apologize to the comfort women survivors and their families. The Japanese government rejected these orders by claiming that those matters had already been settled through the agreement on Japan-South Korea relations' normalization in 1965.

The tension between South Korea and Japan then escalated and impacted various aspects of cooperation that have previously been established. On the economic aspect, South Korea and Japan have excluded each other from the white list of export destination countries. Japan has also restricted the export of high-tech spare parts, which are vital for South Korea. These frictions keep deteriorating and as a countermeasure, South Korea officially announced that it would not renew its membership in GSOMIA three months before the cooperation period ended that year. However, on November 22, 2019, just a few hours before the end of the GSOMIA validity period, South Korea made a surprising decision by aborting its previously self-announced withdrawal from GSOMIA. South Korea declared that it would stay in GSOMIA for an undefined time.

This particular behavior of South Korea is interesting to further scrutinize since the decision to stay in GSOMIA came up in the middle of South Korea and Japan's increasingly heated relations. This study explores the factors that can influence changes in states' behavior reflected in their actions in security cooperation. Based on such a background, this article asks why South Korea reversed its previous self-announced withdrawal from GSOMIA amidst its deteriorating relationship with Japan in 2019.

State behavior in security cooperation is mainly analyzed by scholars in international relations using the alliance theory. Snyder defines an alliance as a formal association of several countries regarding the use (or lack thereof) of military force, which is intended for security or protecting member states, against certain states, either explicitly or not (G. H. Snyder, 1990, p. 104). Snyder briefly 
called alliances as a tool for security against adversaries. A more specific definition is put forward by Niou and Ordeshook (1994), which states that an alliance is a group of countries that are bound together by a collective security strategy respecting each other but not with countries that are outside its membership (Niou \& Ordeshook, 1994, p. 167).

Along with developing contemporary international relations and issues, the alliance theory cannot explain state behavior in security cooperation that occurs indirectly, especially with third-party involvement as a patron state. Therefore, a new concept emerged: quasi-alliance. Cha (2000, p. 262) defines "quasi-alliance" as the relationship between two countries that are not formally allied but have a third party as a patron - typically a great power - as a familiar ally. This consists of two levels of analysis; the inner and outer core. The inner core is the bilateral aspect between the two quasi-allied countries, and the outer core is the multilateral aspect that involves great power as a common ally. A very different definition is conveyed by Degang Sun (2009), who states that quasialliances are formed from permanent or ad hoc informal security cooperation arrangements based on collective defense pacts that are not formal, but are instead agreements between two or more countries or international regimes (Sun, 2009, p. 68). As an instrument of analysis, this article applies Cha's (2000) conceptual premise on quasi-alliance since it describes an actual condition of South Korea and Japan's security partnership with the United States' influence as their patron.

The condition of abandonment and entrapment fears will emerge along with the dynamic relations within quasi-alliance states. According to Cha (2000), when a state is afraid of being abandoned (abandonment fears) it will show a more significant commitment to cooperate, hoping that the partner will do the same. Conversely, a state that is feeling trapped (entrapment fears) will display a faded commitment to cooperate with other parties. Cha also illustrates that a country with a high abandonment fears level can be reflected from various steps it takes to overcome these fears, namely (1) building better internal capabilities, (2) looking for new alliances or strengthening alternative alliances, (3) strengthening their commitment to the alliance to expect their partners to do the same, (4) calming the enemy, or (5) acting as if they are leaving the alliance (bluffing abandonment) to get more significant support from the alliance partner (Cha, 2000, p. 266).

These are what South Korea did. It previously announced the withdrawal from GSOMIA before aborting it and renewing its commitment to the GSOMIA. Furthermore, South Korea also showed efforts to build its internal capacities, especially in regard to security. This is particularly evident with the defense and military budget that kept increasing, from 26 Trillion Won in 2008 to more than 43 trillion Won in 2018 (South Korea Ministry of National Defense, 2018).

Four conditions could lead to abandonment fears, as explained by Cha (2000). First is the perception of external threats. The more intense the threat's perception, the greater the abandonment fears toward its alliance partners will be. Alliances are very commonly seen as a response to threats (Walt, 1985). Perceptions of threats are the results (outcomes) of activities (which can be done) by Party A that are perceived or imagined by Party B (Baldwin, 1971, p. 72). In other words, perceptions are subjective. When a threat is not perceived, there can be no mobilization of resources to carry out a defense even though there is objective evidence. Conversely, threats can be perceived, and defense measures are taken, even when the opponent does not have malicious intentions (Cohen, 1978, p. 93).

The second factor that contributes to abandonment fears is the choice of allies. The lack of options for having alternative partners 
will push the state to maintain its relations with its existing one. Third, the internal balancing capability. This feature is vital since the rupture of the alliance could lead to escalated conflict. Internal balancing capability can be assessed from the state's relative power materials (Treverton \& Jones, 2005). Fourth, the precedent of a partner's appeasement policies toward the threat. Finally, the relations and commitment of common ally or patron. This research will analyze these five factors to assess South Korea's aborted withdrawal from GSOMIA in late 2019.

\section{Enemy of Yesterday, Insincere Alliance of} Today: South Korea - Japan Security Relations

The delicate dynamics of bilateral relations involving South Korea and Japan present three common features. First, the South Korean people's perception is essential in influencing political decisions made by the country's elites regarding cooperation with Japan. Especially after World War II, several distinctive factors have shaped and reshaped such perception, including identity conflict (Nam, 2017), a dualism-perception gap of South Korea's geopolitical interest in relations with Japan (Sohn, 2008), collective memory regarding "past problem" of South Korea-Japan relations (Eun-Mi, 2010), and liberal public discourse (Phillips, Lee, \& Yi, 2019). However, the dual perception is reflected in the identity conflict regarding military cooperation with Japan, as well as the gap of elite perceptions about geopolitical dynamics of the region; the existing liberal public discourse still believes that South Korea and Japan have a realistic opportunity to improve relations along with the emergence of spirit to understand the history empirically.

In regards to the second features, we consider that the decision-making process of South Korea's foreign policy toward Japan has frequently - if not always - become the site for symbolic politics (J. Y. Kim, 2014). Symbolic politics - a mass-led process in South Korea and an elitist process in Japan-have become such a manifestation of the diplomatic conflict resulting from feuds between the conservative elite groups in both countries (J. Y. Kim, 2014). As a result, quite often the two countries put themselves in the position of rhetorical entrapment (Park, 2017). For example, the way the South Korean and Japanese conservative elite groups used symbolic politics before and during the Iraq war had led each country trapped in the awkward opposite position, and regardless they are unified in security cooperation.

The third feature of South Korea and Japan relationships emphasizes the significance of the United States. Despite existing problems in their alliance (A. Kim, 2020), which even amount to a certain degree of distrust (M. Kim, Parker, \& Cho, 2006), the United States will remain the patron for South Korea and Japan's security cooperation. The cooperation itself will keep moving due to mutual understanding and the factor of North Korea as a common threat. The North Korean threat will keep dominating South Korea's current and future national security calculations, and Seoul's alliance with Washington will be a major component of South Korea's national security requirements (Bong, 2016, p. 40).

Those three standard features tell us that South Korea and Japan relations' dynamics challenge the conventional assumption of the balance of threat, which champions that the same perception of threats would make two countries become solid allies (Walt, 1985). The relationship of South Korea and Japan has had significant ups and downs and even tends to be conflictual, regardless of their relative congruence threat perception and United States' influence as their patron. This unique pattern of South Korea - Japan relations makes it an exciting yet challenging case to be examined further.

Furthermore, the common features mentioned above have brought up three consequences, namely: (1) the ups and downs 
of South Korea-Japan relations as well as the causes of improvement and deterioration of relations between the two countries; (2) perception of South Korean people toward Japan and vice versa; and (3) the role of the United States as a common ally for the existence of South Korea and Japan security cooperation. Nevertheless, there has been no specific discussion about South Korean behavior in its quasi-alliance with Japan, especially when it comes to assessing South Korea's decision to abort its withdrawal from GSOMIA in the face of its complicated bilateral relations with Japan.

The escalated tension of South KoreaJapan bilateral relations contrasts with the fact that South Korea finally cancelled its decision to leave GSOMIA and showed its commitment by compromising friction with Japan. The case of South Korea-Japan security cooperation that is being studied in this article deserves further analysis to shed more light on various factors that encourage the continuity of states' cooperation within a quasi-alliance setting. From a larger perspective, this is an important subject to discuss since South Korea and Japan bilateral relations, particularly in the security area, affect their security interest and significantly impact the political-security stability in the East Asia Region. Had their quasi-alliance broken, it might have caused significant geopolitical and geostrategic changes and it would have potentially put East Asia's political-security constellation in limbo.

\section{Method}

This article analyzes South Korea's decision to cancel its withdrawal from security cooperation with Japan. Using the quasialliance concept mentioned earlier, it explains why Seoul annulled its self-announced withdrawal from the General Security of Military Agreement (GSOMIA) in 2019 by looking at the condition of abandonment and entrapment fears faced by the South Korean government.
In analyzing the condition of abandonment fears, this article applies the qualitative research method with a deductive approach. The qualitative research method underlines the depiction of the context to define the research subject's connotation and offers an explanation of a case being studied (Bryman, 2004, pp. 366-367). In this line, the qualitative research method in this article would explain the condition of abandonment fears within the context of South Korean security dynamics, which is used as the basis for Seoul to cancel its withdrawal from GSOMIA in 2019. Meanwhile, the deductive approach implies that this article refers to a theoretical framework and scrutinizes components as units being studied identified from quasi-alliance, namely (1) the perception toward external threats; (2) the choice of allies; (3) the internal balancing capability; (4) partner's appeasement policies toward the threat; and (5) the relations and commitment of common ally or patron.

This article uses primary and secondary data. Primary data are gathered from the South Korean President's public speech and government elites that reflect the South Korean foreign policy, official documents such as defense white paper and other official information issued by the South Korean government. Secondary data used in this research are supporting information needed in explaining the background information of South Korea-Japan quasi-alliance and its character, the US involvement in their relations, and Asia Pacific security as a whole. Those secondary data are gathered from previous studies, scientific journals and reports. The time frame of the data assessed is backtracked from before South Korea announced its intention to leave GSOMIA, when its bilateral relation with Japan began to deteriorate around 20172018, until South Korea officially reversed the decision in November 2019. We then implement the triangulation process to ensure the accuracy and validity of the data and prevent bias of 
perspectives by conducting cross-reference checking (Lamont, 2015) following our research question.

\section{Results and Discussion}

South Korea's decision to stay in GSOMIA with Japan after aborting its previous selfdeclared withdrawal shows that South Korea still needs Japan as a quasi-alliance partner, not to say that it is dependent on this cooperation. This is confirmed with the fact that South Korea even compromised on the ongoing friction in its bilateral relations with Japan. This particular behavior of South Korea reflects the abandonment fears of South Korea or a fear of being ignored by Japan. States in the position of abandonment fears will show a more significant commitment to cooperate in the hope that their partners will do the same (Cha, 2000, p. 268).

The South Korean fear of abandonment might have rooted in its inner core and outer core factors. The first inner core factor is South Korea's perception of North Korea's threat that remains high. This forces South Korea to seek support from allies. Secondly, the limited option of alternative partners also raises the abandonment fears of South Korea. Next, the lack of internal balancing capabilities of South Korea toward Japan inevitably leads South Korea not to prolong its friction with Japan.

Furthermore, the precedent of Japan's appeasement policy to North Korea, which is a common threat for South Korea and Japan, increases its fears of abandonment. From the outer core, the United States' influence as their common ally could not be denied. Current friction and uncertainty commitment of the United States pushes South Korea to maintain its relationship with Japan. These various factors inevitably lead South Korea to consider Japan as the most likely partner choice in the region for now, so it decided to maintain GSOMIA, and in the end, compromised its tensions with Japan.

\section{South Korea's Threat Perception: Threat from the North and Regional Security Dynamics}

One factor that prompted South Korea to cancel its decision to leave GSOMIA is the perception of threat that the country had to overcome alone if it left GSOMIA. Perception of threat can be assessed from four indicators, namely articulation or expression reflected by decision-makers against threats, the embodiment of supporting elements of government, evidence of exploration of various alternatives (such as intensive internal consultation, seeking external support), efforts to overcome threats such as strengthening resource mobilization, and taking diplomatic steps (Cohen, 1978, p. 95). The perception of the threat toward North Korea remains high, which is influenced by its continued nuclear proliferation activity. When a country witnesses another country arming itself, it will be considered to destroy its security; a negative image is attached to the country (Arif, 2016, p. 122). This perception was articulated by South Korean President Moon Jae In during his 100day reign when he said, "I would consider North Korea crossing a red line if North Korea launched another Transcontinental Ballistic Missile and armed it by placing a nuclear warhead on top of the missile" (C. Kim \& Kim, 2017).

North Korea as a perceived threat is also reflected in the Ministry of Defense's regulations and policies. Such a threat perception exists in South Korea's Defense White Paper by detailing the dynamics of South Korea - North Korea relations, as well as data of North Korea's military strength, including sensitive information on its nuclear development (South Korea Ministry of National Defense, 2018). Furthermore, South Korea makes it clear by setting various efforts to overcome this threat, including defense diplomacy as trust-building and military dialogues to prevent potential tensions with North Korea. The South Korean Ministry of National Defense stated that since the 1990s, there had been 169 official military 
dialogues arranged between South Korea and North Korea, including Defense Ministerial talks, General Officer-Level Talks, Military working-level talks, and Military High-Level Talks. However, there was no significant progress in building military trust due to the North's remaining threats and provocative actions (Ministry of National Defense Republic of Korea, 2021).

South Korea's perception of threat should have decreased by the declaration of The Panmunjom for Peace, Prosperity, and Reunification of the Korean Peninsula achieved in 2018, which was envisioned to enlighten the prospect of South Korea improvedrelations with North Korea. Nevertheless, this confidence-building measure is hindered by the stagnancy of the US-North Korea negotiation on denuclearization. Both parties persisted in their position: the US demanded North Korea demonstrate a significant commitment to denuclearization measures before relieving its sanctions, while North Korea pushed the US to end the sanction first as the prerequisite for its denuclearization process. None could expect more for the future of this denuclearization process so that South Korea's perception of threat remains high.

Another aspect that illustrates South Korea's perception of the North Korean threat is South Korea's efforts in exploring alternative responses to overcome that threat; one of them is seeking help from external support (alliances). This underlies the establishment of GSOMIA as an effort by states that perceive North Korea as a threat to seek external support by establishing security cooperation on sensitive military information sharing.

Furthermore, the perception of threat is also affected by the dynamics of states' interaction within the region. The year 2018 was full of vigilance for South Korea due to various political movements and strategic actions of surrounding states, such as China and Russia. At the time, South Korea considered dynamics of the external environment and the East Asian region as a growing uncertainty and instability as mentioned in the South Korea Defense White Paper 2018:

"In Northeast Asia, the strategic
competition between the United States
and China is intensifying, while Japan
and Russia are competitively building
their military strength, mainly their
naval and air forces, to expand their
influence. Such security situation,
combined with the denuclearization
of the Korean Peninsula, is creating
further uncertainties and volatility in
the regional security of Northeast Asia."

In addition, China - one of the countries that supported 2016's UN economic sanctions against North Korea's nuclear developmentseemed to improve its relations with North Korea in 2018. Beijing showed diplomatic support for Pyongyang through various senior military official exchange programs and bilateral economic cooperation. Likewise, as stated in ROK Defense White Paper 2018, North KoreaRussia relations were also getting warmer by the exchanges increased in the commemoration of 70 years of diplomatic relations between Russia and North Korea. In that same year, both countries also agreed to hold a Russia-North Korea Summit during the Russian Foreign Minister's visit to Pyongyang (South Korea Ministry of National Defense, 2018).

These political movements and strategic dynamics around the East Asia Region, especially during 2018-2019, inevitably prompted South Korea to rethink its decision to leave GSOMIA. The perception of the volatile external strategic environment that South Korea described in its 2018 Defense White Paper had shown its concern over strategic moves by North Korea. Around that period, North Korea also appeared to be more active in making approaches to great powers in the region, which unfortunately resulted in antagonism toward South Korea. 
Table 1: GDP and Military Budget of South Korea 2016 - 2019 unit: KRW (billion)

\begin{tabular}{|c|c|c|c|c|}
\hline & 2016 & 2017 & 2018 & 2019 \\
\hline GDP & $1,641,786$ & $1,730,399$ & $1,787,502 \mathrm{p}$ & $1,857,215 \mathrm{e}$ \\
\hline $\begin{array}{l}\text { Military Budget } \\
\text { (billion dollar) }\end{array}$ & $38,800(34.0 \$)$ & $40,335(35.1 \$)$ & $43,158(38.2 \$)$ & $46,697(42.5 \$)$ \\
\hline
\end{tabular}

Source: Obtained from primary data (Ministry of National Defense Republic of Korea, 2019)

\section{South Korea's Limited Options for Alternative Allies}

Allied with the United States, South Korea could not ally with any other states that are either an enemy or a competitor to the United States. This limits alternatives for South Korea to seek alliances within the region other than Japan. Although South Korea has strengthened its military sector by modernizing its military technology and developing the national military industry (Moon \& Lee, 2008), there are still dependencies on the United States regarding protecting its national security, especially in dealing with the North Korean threat. Therefore, even if there are some frictions in South Korea's relations with the United States, the risks are too significant to cheat by allying with other states that would never be approved by the United States.

On the other hand, South Korea's relations with great powers around the region, such as Russia and China, also tend to be antagonistic. During most of the Cold War and the years after, South Korea and Japan faced the same threats, namely China (Sagena \& Moorthy, 2012), the Soviet Union, and North Korea (Cha, 2000, p. 281). Not only opposing the United States, Russia and China are also approached by North Korea. This could eventually threaten South Korea. Such a limited choice for alternative alliances has strengthened Japan's position as the most likely potential ally for South Korea, at least for now. As such, South Korea deeply reconsidered its previous self-announced decision to leave GSOMIA.

\section{South Korea's Lack of Internal Balancing Capabilities vis-à-vis Japan}

South Korea needs to bear with more significant conflict with Japan had it persisted in the previous decision on leaving GSOMIA. Therefore, internal balancing capability is an essential aspect that South Korea considered in formulating its strategic decision. The internal balancing capability can be assessed by comparing states' relative power indicators, including military strength as measured from the military budget, economic wealth reflected from the gross domestic product (GDP), and technological innovation (Treverton \& Jones, 2005, p. ix).

Table 1 above shows that South Korea's defense budget and GDP have increased every year since 2016. South Korea has also developed its domestic military industry to reach independence in military supply (Moon \& Lee, 2008). All the support and incentives provided by the government to the domestic military industry has been able to make South Korea reach the target to fulfill its domestic need for the armament; furthermore, South Korea is recognized as the third-largest arms exporter in the developing world (Chung-in, 1991, p. 445). However, its military-industrial strength is not enough to balance Japan and the other great powers around the region, which also have questionable intention toward South Korea. This unfavorable condition for South Korea is exacerbated by the arms race tendency in the Asia Pacific. During the 20112015 period, SIPRI recorded the Asia Pacific countries as the most prominent weapon 
Figure 1.

\section{The trend of GDP of South Korea vs. Japan (1960-2019) The GDP Trend of South Korea \\ The GDP Trend of Japan}
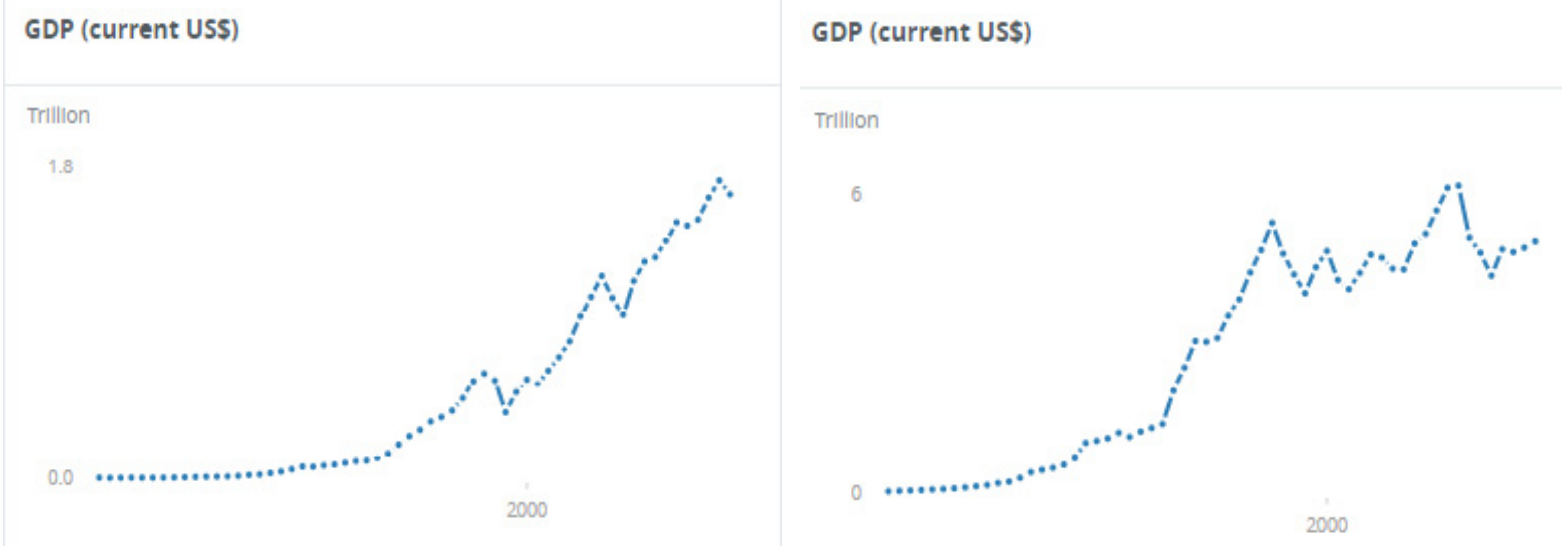

Source: World Bank National Account Data (World Bank, 2020a) (World Bank, 2020b)

importers, about $46 \%$ of the total world's arms imports (Oi-hyun, 2016). Hence, Japan has issued new defense reform legislation to respond to the growing dominance of offensive behavior by the neighboring countries in East Asia (Alghifari \& Letticia, 2016, p. 18). Likewise, the World Bank recorded South Korea's GDP in 2019 is amounting to reach USD 1.647 trillion with more than 51.7 million people of the total population, which is still lower than Japan with a GDP of 5.082 trillion USD and a total population of 126.5 million of people (World Bank, 2020a). Nevertheless, South Korea's GDP shows a relatively increasing trend every year compared to Japan, whose growth tends to slow down.

The internal balancing capability might also come from the excellence in technological innovation (Treverton \& Jones, 2005, p. 14) In this aspect, South Korea is one of the leading countries. Unfortunately, South Korea is highly dependent on Japan to supply high-tech spare parts for Korean industries, especially for the defense industry. South Korea's technologybased defense industry ran into big trouble when the Japanese Ministry of Commerce announced a temporary ban or suspension of export permits for materials vital to the
South Korean semiconductor industry, such as liquid hydrogen fluoride-a chemical used to produce chips (The Japan Times, 2019). Semiconductors are the main source of income for South Korea's Samsung and contributed for $21 \%$ of its total exports (J. Lee, 2018). Thus, deteriorating relations with Japan would be very detrimental to the South Korean economy.

Furthermore, it should be noted that South Korea is striving to bring success to North Korea's current denuclearization program. South Korea needs to be meticulous in each action taken, including managing the source of funding. South Korea always bears a high-cost burden due to the conflict with North Korea, one of the triggers of the unhealthy economy that led to South Korea's financial crisis in 1997 (Tanahsaldy, 1998, p. 41). International financing is critical for the North Korean denuclearization process, considering that many North Korean nuclear projects are hidden in tunnels so that high costs are needed to destroy nuclear facilities and stockpiles (Hornung, 2018). Japan is indeed a desired potential source of funding for this agenda. Thus, leaving the alliance means losing the great funding source to support a sustainable denuclearization process in North Korea. 
Flirting with the Enemy: Japan's North Korea Appeasement Policy

Abandonment fears will increase when the quasi-alliance partner shows a friendly attitude (appeasement policy) toward the threat. A state will feel abandoned when its partner appeases and gets closer to the threat. However, Japan considers North Korea a threat, mainly after North Korea conducted several nuclear and missile tests. Since the Taepondong missile's launch in 1998, which passed over northern Japan, North Korea has launched several missiles at Japan, across Japan and into the Japanese exclusive economics zone (Hornung, 2018). Nevertheless, in March 2019, Japan took appeasement action to win North Korea's heart to smoothen the negotiation process for resolving the kidnapping case that North Korea had committed against Japanese citizens in the 1970-1980s. This is seen when Japan did not participate in submitting a proposal to the UN Human Rights Council against North Korea for the first time. This is contradictory because Japan used to be actively formulating motions for human rights violations by North Korea, and together with the EU submitting them to the UN Human Rights Council every year since 2007 (Hurst, 2019).

In this case, Japan seemed to have its priority on getting along with North Korea. This appeasement was aimed in the context of lobbying North Korea in order to be willing to wrap the negotiations to resolve the case of the kidnapping of Japanese citizens by North Korea. By withdrawing from the annual UN resolution on North Korean human rights, Tokyo sent a signal to Pyongyang (Hurst, 2019).

It was not the first time Japan acted kindly toward North Korea. There was a considerable controversy looking back to the early period of South Korea-Japan normalization of relations in 1965. Such a controversy erupted when Japanese business firms Mitsui and Toho Beslon Co. were reported to export $\$ 40$ million worth of plant equipment for manufacturing acrylic fiber to North Korea. The controversy also occurred when the Japanese government decided to allow North Korean technicians to inspect the machines in Japan in July 1966 (Far Eastern Economic Review, 1966, p. 340). The South Korean government announced that such a move would not only violate the newly crafted 1965's Treaty on Basic Relations between Japan and the Republic of Korea (widely known as normalization pacts) but also helped North Korean war preparations for attacking South Korea (Ko, 1972, p. 57). In addition, the policy of repatriation of North Korean citizens from Japan and recognition of educational institutions that are pro-North Korean in Japan (Ko, 1972, pp. 56-59) added to the long list of Japan appeasement policies to North Korea that led to protests from South Korea. South Korea views any contact between Tokyo and Pyongyang as an act of ungratefulness that undermines Seoul's efforts to maintain regional stability (Cha, 2000, p. 271).

\section{Unreliable Patron: US' Strategic Commitment and South Korea - US Relations}

South Korea and the US have become close partners in security cooperation since the signing of the US-South Korea Mutual Defense Treaty in 1953. Since then, the United States has become such a "protector" for South Korea, especially regarding defense mechanisms against the North Korean threats. The US places around 28,500 troops in South Korea, which is part of the United States "nuclear umbrella" program (Manyin, Chanlett-Avery, \& Williams, 2019).

However, 2018-2019 was not the best year for South Korea - US bilateral relations. At least two issues trigger friction in their security partnership, namely the problem of different approaches to North Korea's denuclearization taken by the US and the issue of the contribution of military costs. On the one hand, Moon supported Trump's 
"maximum pressure" campaign toward North Korea denuclearization. On the other hand, South Korea also maintains its preference for embracing North Korea (Manyin et al., 2019). Moon fears that a coercive approach to North Korea will lead to potential retaliation from North Korea that could threaten the Korean Peninsula's stability.

Regarding cost-sharing of military cooperation, the United States demanded South Korea to increase its contribution, forcing South Korea to accept a Special Measure Agreement that increased its contribution by $8 \%$, from 800 million dollars to 924 million dollars in the beginning of 2019 (Manyin et al., 2019). Trump insisted that US allies should pay for the security guarantee (Bisley, 2020). He pushed South Korea to increase its contribution of up to 4.7 billion dollars for the next year, including several new post burdens, such as military equipment, operational, and training costs for American troops outside South Korea related to securing the Korean Peninsula (S. A. Snyder, 2019). South Korea's objection to this request then raised the discourse in the US government about reducing American troops and accused the former as a free rider (S. A. Snyder, 2019). Furthermore, the United States also moved its military camp to the south away from the South Korean border with North Korea, with a $94 \%$ cost percentage borne by South Korea (Manyin, Chanlett-Avery, \& Williams, 2021).

These uncertain relations were then exacerbated by inconsistency - not to say declining - of the US commitment toward the security affairs in North-East Asia. Compared to Obama, the Trump administration had so far been more explicit in seeing China as a longterm geopolitical rival as well as concern about North Korean nuclear proliferation but has not yet made substantive changes to the US security policy to match this declaratory shift (Bisley, 2020, p. 162). Unpredictability and wild policy swings had been the central feature of Trump's incoherent and inconsistent policies toward
East Asia during his term as president of the US (Matray, 2018). This situation has given South Korea doubt about the US commitment in facing Asia's security challenge. Therefore, South Korea ought to prepare for the worst in the middle of the US' diminished role by keeping Japan close.

\section{US Inconsistency: South Korea's Threat Perception Signifiers}

Uncertainty of the US commitment toward the security challenge in East Asia and unstable relations with South Korea increase the perception of South Korea's security threat. Borrowing Cha's assumption (2000, p. 263), when there are high degrees of security dependence on the patron, the patron commitment level can magnify threat-induced pressures on alliance behavior. Although domestically there are both opposition and affirmative groups that influence the country's foreign policy toward the United States (Darussalam, 2020), South Korea has always been concerned with US commitment. The lesson learned from the Korean War was that South Korea suffered significant losses shortly after America withdrew its troops from South Korea in 1949. The historical experience of national insecurity among the absence of great power allies prompted South Korea to immediately seek an alliance partner. This goal was reached when the Mutual Defense Treaty between South Korea and the US was established in 1953 (Chun, 2000). Going back to the current dynamics of US-South Korea relations and uncertainty of US commitment in the region, South Korea needs to reconsider its intention to leave GSOMIA. The current US security policy in Asia is stuck somewhere between inertia and neglect, prompting friends and allies to accelerate their planning for a region in which the United States plays a more diminished role (Bisley, 2020, p. 162).

Hence, assessing the US attitude in the above sections shows how the outer factor 
has raised concerns among the South Korean security policymakers that their country needs reliable backup partners, inevitably increasing its abandonment fears toward Japan as its quasi-alliance. The limited choice of alternative alliances other than Japan (especially in the region) and the high risk that South Korea has to bear without having security support from the alliance are becoming obstacles to exit. As Cha (2000) correctly posits, this condition will push the two quasi-alliance states to strengthen their bilateral cooperation. It seems preferable for South Korea to compromise its current friction with Japan rather than bearing alone with the North Korean threat and put its security at risk.

\section{Conclusion}

The years 2018 and 2019 were allegedly the worst phase in South Korea-Japan relations since the normalization of relations in 1965 . The reemergence of the historical issue of past Japanese atrocities against South Korea had escalated to the economic aspect that hampered the semiconductor chip industry vital to South Korea's economy and its national defense. The deteriorating tensions prompted South Korea to issue an official statement in August 2019 announcing that it would withdraw from GSOMIA. However, in November 2019, before the end of the cooperation period, South Korea reversed its decision to leave GSOMIA.

South Korea preferred to commit to GSOMIA even though it currently has severe problematic relations with Japan. This research shows that South Korea was experiencing abandonment fears toward their ally. This is due to several factors, including its inner and outer core of quasi-alliance with Japan. South Korea was still in a high perception of North Korea's threat that was exacerbated by the region's political dynamics and uncertain commitment from the United States. Leaving the alliance would mean that South Korea had to face the threats alone. Even though
South Korea had been developing its military capabilities, as seen from its efforts to increase its military budget consistently every year, it has not significantly increased its internal balancing capability against Japan, Russia, or China. It is therefore not favorable for South Korea to stand alone to "balance" these great powers in the region without GSOMIA.

The lack of alternative alliances in the region also made South Korea admit Japan as its most likely partner choice. Several appeasement actions of Japan to North Korea in the past only increased South Korea's abandonment fears. Concomitantly, South Korea could not rely on the United States due to the latter uncertain relations and inconsistency in the foreign and security policy's commitment in the Northeast Asia region. Again, these unfavorable conditions pushed South Korea to retain its partnership with Japan. South Korea would have had to bear too much of the burden and cost alone had it persisted in leaving the alliance. Compromising its conflict with Japan is thus the most likely choice to take in the current security dynamics. Hence, when facing severe abandonment fears, maintaining the quasi-alliance even with a dilemmatic partner(s) remains the best worst policy alternatives for a state to pursue.

\section{Acknowledgments}

We would like to thank the journal's anonymous reviewers for their thoughtful comments on earlier versions of the article, the journal's editors for their practical guidance during the publication process, as well as the journal's copyeditor and M. Halil Rahim for proofreading the article.

\section{References}

Alghifari, F., \& Letticia. (2016). Analisis Teori Offense-Defense terhadap Reformasi Kebijakan Pertahanan Jepang dalam Dinamika Keamanan di Asia Timur. Global: Jurnal Politik Internasional, 18(1), 18-33. doi:10.7454/global.v18i1.45 
Arif, M. (2016). How Threat Assessment Could Become Self-Fulfilling Prophecy: Case of U.S-China Relation. Global: Jurnal Politik Internasional, 18(2), 120-130. doi:10.7454/ global.v18i2.140

Baldwin, D. A. (1971). Thinking about Threats. The Journal of Conflict Resolution, 15(1), 71-78.

bbc.com. (2018, 29th of November). Mitsubishi Heavy ordered to compensate forced $S$ Korean war workers. BBC. Retrieved from https://www.bbc.com/news/ business- 46381207

Bisley, N. (2020). Security Policy in Asia from Obama to Trump: Autopilot, neglect, or worse? In O. Turner \& I. Parmar (Eds.), The United States in the Indo-Pacific: Obama's Legacy and the Trump Transition (pp. 161-176). Manchester: Manchester University Press.

Bong, Y. D. (2016). The U.S.-South Korea Alliance: Local, Regional, and Global Dimensions. Asian Politics \& Policy, 8(1), 39-49. doi: https://doi.org/10.1111/aspp.12242

Bryman, A. (2004). Social Research Methods (2nd ed.). Oxford: Oxford University Press.

Cha, V. (2000). Abandonment, Entrapment, and Neoclassical Realism in Asia: The United States, Japan, and Korea. International Studies Quarterly, 44(2), 261-291.

Chun, C.-S. (2000). Theoretical Approaches to Alliance: Implications on the R.O.K.-U.S. Alliance. Journal of International and Area Studies, 7(2), 71-88. doi:http://www.jstor. com/stable/43111426

Chung-in, M. (1991). The Political Economy of Defense Industrialization in South Korea: Contraints, Oopportunities, and Prospects. The Journal of East Asian Affairs, 5(2), 438-465. Retrieved from http://www. jstor.com/stable/23253549

Cohen, R. (1978). Threat Perception in International Crisis. Political Science Quarterly, 93(1), 93-107.

Darussalam, M. F. (2020). The Influence of
Domestic Politics of South Korea on its Relations with North Korea and the United States. Jurnal Ilmu Sosial dan Ilmu Politik, 23(3), 250-261. doi:10.22146/ jsp.48652

Eun-Mi, C. (2010). Memory Politics and International Relations in East Asia - Focusing on "Past Problem" between South Korea and Japan. International Area Review, 13(2), 63-79.

Far Eastern Economic Review. (1966). Far Eastern Economic Review, LIII(8).

Hayashi, H. (2008). Disputes in Japan over the Japanese Military "Comfort Women" System and Its Perception in History. The Annals of the American Academy of Political and Social Science, 617, 123-132. Retrieved from https://www.jstor.org/ stable/25098017

Hornung, J. W. (2018). Success with North Korea Still Needs Japan. RAND - Commentaries.

Hurst, D. (2019, 19th of March). Japan Takes Small Step Toward Diplomacy With North Korea. The Diplomat. Retrieved from https://thediplomat.com/2019/03/japantakes-small-step-toward-diplomacy-withnorth-korea/

Japan Press Weekly. (2018, 28th November). Korean top court orders Mitsubishi Heavy Industries to pay damages to wartime forced laborers. Japan Press Weekly. Retrieved from https://www. japan-press.co.jp/s/news/?id=11887

Kim, A. (2020). Understanding Japan-South Korea Cooperation and Friction Through Neoclassical Realist Theory. Jadarpur Journal of International Relations, 24(I), 28-52.

Kim, C., \& Kim, C. (2017, 17th of August). South Korea's Moon Says North Korean NuclearTipped ICBM is a 'Red Line'. Jakarta Globe. Retrieved from https://jakartaglobe.id/ news/south-koreas-moon-says-northkorean-nuclear-tipped-icbm-red-line/

Kim, J. Y. (2014). Escaping the Vicious Cycle: Symbolic Politics and History Disputes 
Between South Korea and Japan. Asian Perspective, 38(1), 31-60. Retrieved from https://www.jstor.org/stable/42704853

Kim, M., Parker, S. L., \& Cho, J. Y. (2006). Increasing Distrust of the USA in South Korea. International Political Science Review, 27(4), 427-445.

Ko, S. K. (1972). South Korean-Japanese Relations since the 1965 Normalization Pacts. Modern Asian Studies, 6(1), 49-61. Retrieved from https://www.jstor.org/ stable/311986

Korostelina, K. V. (2017). The normative function of national historical narratives: South Korean perceptions of relations with Japan. National Identities, 1-19. doi:1 0.1080/14608944.2017.1401599

Lamont, C. (2015). Research Methods in International Relations. London: Sage Publicatios Ltd.

Lee, J. (2018, 28th of November). Korea's Huge Bet on Semiconductor Exports Adds Risks to Economy. Bloomberg. Retrieved from https://www.bloomberg.com/news/ articles/2018-11-27/korea-s-huge-bet-onsemiconductor-exports-adds-risks-toeconomy

Lee, M. C. (Producer). (2019). The Strategic Value of the General Security of Military Information Agreement. Retrieved from https://www.defenceiq.com/cyberdefence-and-security/articles/the-valueof-the-general-security-of-militaryinformation-agreement-gsomia

Manyin, M. E., Chanlett-Avery, E., \& Williams, B. R. (2019). South Korea: Background and U.S. Relations. Retrieved from

Manyin, M. E., Chanlett-Avery, E., \& Williams, B. R. (2021). South Korea: Background and U.S. Relations (IF10165). Retrieved from United States: https://fas.org/sgp/crs/row/ IF10165.pdf

Matray, J. I. (Producer). (2018). Inconsistent, Incoherent, and Unpredictable: U.S.
Policies in East Asia under President Donald J. Trump. America and the World-2017 and Beyond. [Essay] Retrieved from https://issforum.org/ISSF/PDF/ Policy-Roundtable-1-5BF.pdf

Min, P. G. (2003). "Comfort Women" The Intersection of Colonial Power, Gender, and Class. Gender \& Society, 17(6), 938-957. doi:10.1177/0891243203257584

Ministry of National Defense Republic of Korea. (2019). Status of Defense Budget over the Last 4 Years. Retrieved from https:// www.mnd.go.kr/mbshome/mbs/mndEN/ subview.jsp?id=mndEN_030900000000

Ministry of National Defense Republic of Korea. (2021). Defense Policy: Establishment of Military Trust in Inter-Korean Relations. Retrieved from https://www.mnd. go.kr/mbshome/mbs/mndEN/subview. jsp?id=mndEN_030200000000

Moon, C.-i., \& Lee, J.-Y. (2008). The Revolution in Military Affairs and the Defence Industry in South Korea. Security Challenges 4(4), 117-134. Retrieved from http://www.jstor. com/stable/26459813

Nam, C.-h. (2017). Can South Korea Embrace Japan's Expanding Security Role? Sources and the Manifestation of the Conflicting Identities. Pasific Focus, XXXII(3), 396-415. doi:doi: 10.1111/pafo.12103

Niou, E. M. S., \& Ordeshook, P. C. (1994). Alliances in Anarchic International Systems. International Studies Quarterly, 38(2), 167-191.

Oi-hyun, K. (Producer). (2016). Reports point to a new arms race breaking in the Asia Pacific region.

Park, S.-H. (2017). Rhetorical entrapment and the politics of alliance cooperation: explaining divergent outcomes in Japan and South Korea during the Iraq War. International Relations, 31(4), 484-510. doi:https://doi. org/10.1177/0047117817726362

Phillips, J., Lee, W., \& Yi, J. (2019). Future of South Korea-Japan Relations: Decoupling 
or Liberal Discourse. The Political Quarterly, 19(2), 448-456. doi:https://doi. org/10.1111/1467-923X.12786

Ponizilova. (2017). Stability of Regional Orders in Contemporary International System: A Framework for Analysis Journal of International Relations - University of Economics in Bratislava, XV(2), 182-207.

Sagena, U. W., \& Moorthy, R. (2012). Keamanan Energi dan Hubungan Kerja Sama CinaJepang. Jurnal Ilmu Sosial dan Ilmu Politik, 16(2), 136-152.

Snyder, G. H. (1990). Alliance Theory: A Neorealist First Cut. Journal of International Affairs, 44(1), 103-123. Retrieved from https://www.jstor.org/stable/24357226

Snyder, S. A. (2019, 26th of November). U.S.South Korea Tensions: What's at Stake? Retrieved from https://www.cfr.org/inbrief/us-south-korea-tensions-whats-stake

Sohn, Y. (2008). South Korea's Japan Policy under the New ROK Government. The Journal of East Asian Affairs, 22(1), 33-56. Retrieved from https://www.jstor.org/ stable/23257873

South Korea Ministry of National Defense, S. K. (2018). Defense White Paper 2018. Retrieved from https://www.mnd. go.kr/user/mndEN/upload/pblictn/ PBLICTNEBOOK_201908070153390840. pdf

Sun, D. (2009). Brothers Indeed: Syria-Iran Quasi-alliance Revisited. Journal of Middle Eastern and Islamic Studies (in Asia), 3(2),
67-80. doi:10.1080/19370679.2009.12023 132

Suseto, B., Othman, Z., \& Razalli, F. M. (2019). Assessing the Evolution of Maritime Strategy in the Asia Pacific. Jurnal Ilmu Sosial dan Ilmu Politik, 23(2), 87-101. doi:10.22146/jsp.41709

Tanahsaldy, T. (1998). Chaebol: Kesuksesan dan Kemunduran Ekonomi Korea. Global: Jurnal Politik Internasional, 5, 39-50. Retrieved from http://global.ir.fisip.ui.ac. id/index.php/global/article/view/187/94

The Japan Times, J. (2019). Japan delaying export of key chipmaking material beyond 90-day limit, South Korea says. Retrieved from https://www.japantimes. co.jp/news/2019/10/01/business/japandelaying-export-chipmaking-materialsouth-korea/\#.X0YgrcgzbIU

Treverton, G. F., \& Jones, S. G. (2005). Measuring National Power, United States.

Walt, S. M. (1985). Alliance Formation and the Balance of World Power. International Security, 9(4), 3-43.

World Bank. (2020a). Korea, rep. Retrieved from https://data.worldbank.org/country/ korea-rep. from World Bank https://data. worldbank.org/country/korea-rep

World Bank. (2020b). World Bank National Account Data. Retrieved from https://data.worldbank.org/country/ japan?view=chart. from World Bank https://data.worldbank.org/country/ japan?view=chart 